FILOZOFIA

Roč. 75,2020 , č. 5

DOI: https://doi.org/10.31577/filozofia.2020.75.5.3

\title{
EXISTENCIA, SUBJEKTIVITA, ETIKA. REFLEXIA KIERKEGAARDA V NEMECKEJ A FRANCÚZSKEJ FENOMENOLÓGII
}

\author{
PETER ŠAJDA, Filozofický ústav Slovenskej akadémie vied, Bratislava, SR \\ ŠAJDA, P.: Existence, Subjectivity, Ethics. The Reception of Kierkegaard in \\ German and French Phenomenology \\ FILOZOFIA, 75, 2020, No 5, pp. $372-385$ \\ The paper represents a contribution to a broader discussion of the relation be- \\ tween the phenomenological and the existential tradition. It explores the re- \\ ception of Kierkegaard's philosophy in the writings of three phenomenological \\ authors: M. Heidegger, E. Levinas and M. Henry. Their Kierkegaard reception \\ is the most intensive among phenomenological thinkers and focuses largely on \\ the issues of existence and subjectivity and their ethical-religious dimension. \\ I analyze the main motifs of this reception and point out the overlaps, contra- \\ dictions and tensions between the different interpretations of Kierkegaard's ide- \\ as. I also suggest potential topics for future research.
}

Keywords: Phenomenology - Philosophy of existence - Søren Kierkegaard - Existence - Subjectivity - Ethics

Predkladaný článok je príspevkom k výskumu vzt’ahu fenomenologickej a existenciálnej tradície. Obidve tradície sú v našom priestore živé a stále vznikajú nové diela, ktoré ich skúmajú, rozvíjajú a kriticky reflektujú. Za posledných dvadsat' rokov sa u nás venovala značná pozornost' kl'účovej postave filozofie existencie Sørenovi Kierkegaardovi, ktorou sa budem zaoberat' aj v tomto príspevku. Otázka Kierkegaardovho vplyvu na fenomenológiu zaznieva už od počiatku fenomenologického hnutia. Hoci najmä posledné roky priniesli v medzinárodnom prostredí nové podnety $\mathrm{k}$ tejto téme, $\mathrm{v}$ našom prostredí sa jej zatial' nevenovala väčšia pozornost'. ${ }^{1}$ Ciel'om príspevku je nastolit' túto tému, určit' jej základné súradnice a naznačit' smer d’alšieho výskumu. V prvej časti predstavím fenomén kierkegaardovskej renesancie, ktorý bol súčast'ou kontextu, v ktorom fenomenologické hnutie vzniklo. V d’alších dvoch častiach načrtnem základnú líniu recepcie Kierkegaardovho myslenia u klúčových postáv fenomenologickej tradície. Zameriam sa na myslitel'ov, ktorí

\footnotetext{
${ }^{1}$ Výnimkou je Heideggerova recepcia Kierkegaarda, ktorou sa zaoberajú viaceré diela, ktoré vyšli na Slovensku a v Čechách. Nižšie odkazujem na niektoré z nich.
} 
najvýraznejšie reflektovali jeho idey: M. Heideggera, E. Levinasa a M. Henryho. Budem sledovat' výlučne ich explicitnú recepciu a objasním jej hlavné momenty. V poslednej časti vyhodnotím a porovnám charakteristiky skúmanej recepcie. Predstavené analýzy a záverečná bilancia umožnia lepšiu orientáciu v komplexnom vzt'ahu fenomenológie a filozofie existencie.

\section{Kontext vzniku fenomenologickej recepcie Kierkegaarda: kierkegaardovská renesancia}

Ak chceme porozumiet' kontextu, v ktorom fenomenologická recepcia Kierkegaarda vznikla, musíme aspoň rámcovo približit' fenomén kierkegaardovskej renesancie. Toto pomenovanie sa vzt’ahuje na vel'kú vlnu záujmu o Kierkegaarda, ktorá zasiahla nemecky hovoriaci priestor v rokoch $1909-1945$. $^{2}$ Široké spektrum filozofov, teológov, psychológov a literátov nadviazalo na Kierkegaardov myšlienkový odkaz a v intelektuálnej obci sa rozprúdil živý diskurz o jeho význame. S reflexiou Kierkegaardových myšlienok sa stretávame v ideových prúdoch, ktoré rozhodujúcim spôsobom formovali intelektuálny život. Kierkegaardovo meno sa spája predovšetkým s tradíciou existenciálnej filozofie, ktorej hlavným predstavitel’om bol Karl Jaspers. So silným ideovým vplyvom Kierkegaarda sa stretávame v prostredí protestantskej dialektickej teológie - v dielach Karla Bartha, Emila Brunnera, Paula Tillicha, Friedricha Gogartena a Rudolfa Bultmanna. Dynamická diskusia o Kierkegaardovi sa rozvinula medzi neomarxistickými myslitel'mi, ktorí sa v rôznej miere spájali s Frankfurtskou školou. Inicioval ju Siegfried Kracauer, najvýraznejšie sa do nej zapojil Theodor W. Adorno a originálnymi pohladmi prispeli aj Walter Benjamin a Max Horkheimer. Niekol'ko súbežných diskurzných línií vidíme v katolíckej intelektuálnej obci. V skupine okolo časopisu Hochland spopularizovali kierkegaardovské motívy najmä Theodor Haecker a Romano Guardini, v periodiku Stimmen der Zeit zase Erich Przywara. Kritické vyrovnávanie sa s Kierkegaardom bolo súčast'ou aj formujúcej sa filozofie dialógu, pričom Ferdinand Ebner a Martin Buber interpretovali Kierkegaarda v personalistickom duchu. V rámci kierkegaardovskej renesancie existovala aj národnosocialistická línia, ktorú reprezentovali Alfred Baeumler a Emanuel Hirsch a s ktorou verejne polemizovali Tillich a Adorno. Súčast'ou kierkegaardovskej renesancie boli aj d’alší myslitelia, ktorí nepatrili k žiadnemu z uvedených prúdov.

Kierkegaardovská renesancia sa v medzivojnovom období rozšírila do d’alších krajín. Vo Francúzsku dochádza v tridsiatych rokoch k súbehu viacerých intelektuálnych iniciatív. Vychádzajú nové preklady Kierkegaardových diel od Paula-Henriho

2 Termín kierkegaardovská renesancia sa prvýkrát vyskytuje u Wernera Elerta (Elert 1921, 432). Podrobnejší opis tohto fenoménu možno nájst' v mojej práci (2016). 
Tisseaua, Jean Wahl a Lev Šestov publikujú vplyvné interpretácie Kierkegaarda, o Kierkegaardovi sa diskutuje v prostredí francúzskeho barthizmu a časopisy Foi et Vie a Hic et Nunc sa stávajú platformami diskurzu o jeho myslení.

Fenomenologické hnutie v Nemecku i Francúzsku sa rozvíjalo súbežne s kierkegaardovskou renesanciou a čiastočne sa s ňou prekrývalo. Viacerí jeho predstavitelia recipovali Kierkegaardove idey a aktívne sa zapojili do prebiehajúceho diskurzu. V druhej polovici 20. storočia na ich recepciu nadviazali d’alší autori.

\section{Heidegger a otázka existencie}

$\mathrm{Na}$ rozdiel od zakladatel'a fenomenologického hnutia E. Husserla, ktorého recepcia Kierkegaarda je skromná, ${ }^{3}$ Heidegger patril k centrálnym postavám kierkegaardovskej renesancie. ${ }^{4} \mathrm{~K}$ samotnej renesancii sa však Heidegger staval kriticky. V prednáškovom cykle Základné pojmy metafyziky ju komentoval takto: „[D]nes, ked’ sa Kierkegaard z nejakých dôvodov stal módou, sme dospeli až tam, že táto kierkegaardovská literatúra a všetko, čo sa ňou obklopuje, sa všemožne usiluje nepochopit' to, čo je rozhodujúce v Kierkegaardovej filozofii“ (Heidegger 1992, 225). Predtým, ako sa pokúsime identifikovat' to, čo sám Heidegger považoval za rozhodujúce v Kierkegaardovej filozofii, uved'me, že Heidegger sledoval Kierkegaardov prienik do Nemecka už pred kierkegaardovskou renesanciou. V druhej sérii prednášok o Schellingovi podotýka, že Kierkegaard už „od roku 1900 pôsobí mnohými spôsobmi, súbežne s Nietzschem“ (Heidegger 1991, 19).

Pri analýze Heideggerovej recepcie sa vel'ká čast' staršej výskumnej literatúry zameriavala na tri poznámky pod čiarou v Bytí a čase, v ktorých Heidegger odkazuje na Kierkegaarda. Autori z nich odvodzovali možné implicitné vplyvy. Pre nás je smerodajný najnovší výskum, ktorý sa na základe analýzy súbornej edície Gesamtausgabe usiluje predstavit' čo najkomplexnejší obraz Heideggerovej explicitnej recepcie. Za najdôležitejšie výskumné dielo považujeme monografiu Gerharda Thonhausera Tajomné znamenie. O vzt'ahu Martina Heideggera a Sørena Kierkegaarda, ktorá priniesla sériu užitočných zistení (Thonhauser 2016, 145 - 161). Z hl'adiska nášho výskumu sú dôležité najmä dve: 1 . V rámci celého korpusu Heideggerových spisov sa najviac odkazov na Kierkegaarda nachádza v podkladoch $\mathrm{k}$ prednáškam a seminárom, ktoré viedol na univerzitách vo Freiburgu a Marburgu. Najmenej odkazov sa nachádza vo vydaných dielach. Celkovo sa v rámci Gesamtausgabe

\footnotetext{
${ }^{3}$ Husserl nespomína Kierkegaarda v publikovaných dielach ani v prednáškach, no odkazuje naňho v poznámkach a listoch. Husserlov pohl'ad na kierkegaardovskú renesanciu i jeho reflexiu Kierkegaardovej koncepcie existencie analyzuje Jamie Turnbull (Turnbull 2012, 151 - 156). Pre kontext Husserových úvah o Ja v tridsiatych rokoch 20. storočia pozri Vydrová (2013).

${ }^{4}$ Heideggerovej recepcii Kierkegaarda sa v našom prostredí venujú napríklad Šajda (2017), Olšovský (2013), Thonhauser (2016b).
} 
nachádza 139 strán, na ktorých Heidegger explicitne spomína Kierkegaarda: 84 strán predstavujú prednáškové a seminárne materiály, 34 strán d’alšie nevydané rukopisy, poznámky a listy, 21 strán vydané diela. Komplexný obraz Heideggerovej recepcie Kierkegaardových ideí vyžaduje zohl'adnenie všetkých týchto materiálov. 2. Základ pre periodizáciu Heideggerovej recepcie Kierkegaardovho myslenia predstavujú podklady k prednáškam a seminárom. Vydané diela a iné nevydané materiály poskytujú len doplnkové informácie. Heideggerovu recepciu môžeme rozčlenit' do piatich fáz: Prvá patrí do raného freiburského obdobia (1919 - 1923) a charakterizuje ju kontinuálne vyrovnávanie s Kierkegaardom. Druhú fázu ohraničuje pôsobenie v Marburgu (1923 - 1928) a dochádza v nej k oslabeniu explicitnej reflexie Kierkegaardových ideí. V tomto období vychádza Bytie a čas. V tretej fáze - od Heideggerovho návratu do Freiburgu, až kým sa vzdal rektorského úradu (1928 - 1934) - sa zintenzívňuje Heideggerov záujem o Kierkegaarda a narastá počet explicitných odkazov. V štvrtej fáze, ktorá sa začína Heideggerovými kurzami v roku 1935 a končí sa v roku 1944, ked' prestáva prednášat', klesá intenzita explicitnej recepcie, no pozoruhodnou výnimkou je rok 1941. V piatej fáze Heideggerovho neskorého pôsobenia sú odkazy na Kierkegaarda zriedkavé.

Hoci Heideggerova explicitná recepcia prebiehala počas štyroch desat'ročí, rozsah jej tém je pomerne úzky. Jej stredobodom je pojem existencie a s ním súvisiace koncepcie bytia sebou a vol'by seba samého. Od existencie sa odvíjajú d’alšie témy: okamih a existenciálny význam časovosti, paradox a vzt’ah jedinca k transcendencii, existenciálna výzva úzkosti. Heidegger sa tiež zaoberá situovaním Kierkegaarda v dejinách myslenia, opakovane sa venuje jeho vzt’ahu k Hegelovi a Nietzschemu.

Prirodzeným východiskom analýzy Heideggerovej explicitnej recepcie sú tri spisy z roku 1941, v ktorých sa najpodrobnejšie zaoberá Kierkegaardom. Rukopis diela Náčrty k dejinám bytia ako metafyziky obsahuje najintenzívnejšie vyrovnávanie s Kierkegaardom v rámci vydaných diel, podklady k prednáškam o Schellingovi obsahujú najrozsiahlejšiu reflexiu Kierkegaardovho myslenia v celom korpuse Heideggerových textov a úvaha s názvom Môj vztah ku Kierkegaardovi z Čiernych zošitov je Heideggerovým vlastným hodnotením jeho recepcie. Tento súbor textov obsahuje Heideggerovu najkomplexnejšiu a najsystematickejšiu reflexiu Kierkegaardovho myslenia.

Najkratším textom je Môj vzt’ah ku Kierkegaardovi, v ktorom Heidegger objasňuje základný moment inšpirácie Kierkegaardom. Zároveň sa voči Kierkegaardovi vymedzuje a zdôrazňuje originalitu vlastného ideového projektu. Odmieta interpretáciu, že jeho myslenie - najmä dielo Bytie a čas - je len ateistickou 
redukciou Kierkegaarda. Upozorňuje, že otázka bytia, ktorú sám nastol'uje, je celej metafyzike vrátane Kierkegaarda cudzia. Otvorene však priznáva inšpiráciu Kierkegaardom: „Prečo sa potom [v diele Bytie a čas] vyskytuje ,Kierkegaard“ a prečo preberáme jeho terminológiu a ,existencia‘ je ,existencielná‘? - Lebo tu máme v rámci západnej metafyziky, a síce novovekej, pokus bytostne pochopit’ bytie sebou človeka zo subjektivity“" (Heidegger 2014, 215). Podobne ako v Bytí a čase aj tu Heidegger poukazuje na dôležitost' Kierkegaardových formačných spisov, ktoré opisujú jedincovo bytie sebou: „,Filozoficky‘, v zmysle otázky bytia, ktorú kladieme, sa môžeme viac naučit’ $\mathrm{z}$ formačných spisov, lebo v nich spoznávame to, čo je existencielné, bytie sebou, a nie hegelovskú metafyziku. No Kierkegaardovo bytie sebou čítame v Bytí a čase pôvodnejšie - to znamená: čítame ho existenciálne“ (Heidegger 2014, 216). Heidegger dodáva, že pre Kierkegaarda je bytie sebou bytostne späté s krest’anskou formáciou, no on sám $\mathrm{k}$ nemu pristupuje spôsobom, ktorý nie je ,ani krest’anský, ani protikrest'anský“ (Heidegger 2014, 215 - 216).

V diele Náčrty dejín bytia ako metafyziky Heidegger sumarizuje základné charakteristiky Kierkegaardovho pojmu existencie a začleňuje ho do širšieho dejinno-filozofického prehl'adu koncepcií existencie od antiky po súčasnost'. Jeho základnou tézou je, že u Kierkegaarda dochádza k radikálnemu „zúženiu“ pojmu existencie, ked’že spomedzi všetkých súcien sa existencia vzt’ahuje len na človeka, a to len vtedy, ked’ rozvíja určité vzt'ahové dynamiky (Heidegger 1961, 475 - 476). Existencia predpokladá zaujatost' skutočnostou a zdarnú realizáciu dvoch vzt’ahov: k sebe samému a k Bohu. Týka sa výlučne „súcna, ktoré ,je“ v rozpore časovosti a večnosti: človeka, ktorý chce byt' sám sebou. Existovanie ako viera, to znamená: držat' sa skutočnosti skutočného, ktorým je vždy sám človek“" (Heidegger 1961, 475). Existencia je totožná s vierou preto, lebo človek sa stáva sám sebou pred Bohom. Vzt’ah k sebe samému a k Bohu sú spojené dynamiky. Viera nie je epistemologický akt uznania pravdivosti určitej náuky, ale interpersonálny vzt'ahový akt. Prejavuje sa v tom, že človek sa „stáva zjavným pred Bohom“ a vstupuje do vzt'ahu „k pravdivému ako skutočnému“, s ktorým konkrétne „zrastie“ (Heidegger 1961, 477 - 478). Tento vzt’ahový akt má krest'anský obsah, ked’že náprotivkom človeka je Boh, ktorý sa stal človekom. Existencia ako viera je teda takou sebainterpretáciou a sebaformáciou človeka, ktorá je v súlade s tým, kým je zoči-voči Bohu. Existencia je „bytie krest’anom v zmysle stávania sa krest'anom“ (Heidegger 1961, 475). Podl'a Heideggera táto línia uvažovania zužuje pojem existencie na „krest’anskost' bytia krest’anom" (Heidegger 1961, 480).

Najpodrobnejšia reflexia Kierkegaardovho myslenia sa nachádza v druhom cykle prednášok o Schellingovi. Jej východiskom sú dva citáty z Kierkegaardovho diela Záverečný nevedecký dodatok a zo zápisníkov z roku 1835. Heidegger v nich 
identifikuje dva protiklady, na základe ktorých vysvetl'uje Kierkegaardov pojem existencie: 1. existovat' a abstraktne mysliet'; 2. len tak existovat' a opravdivo existovat'.

V súvislosti s prvým protikladom Heidegger poznamenáva, že abstraktné myslenie sa u Kierkegaarda jednoznačne vzt’ahuje na Hegelovu metafyziku. Tá predpokladá myslitel'a, ktorý myslí absolútno a sústredí sa výlučne na to, čo je všeobecné. Existencia ako každodenný spôsob myslenia a konania jednotlivého človeka je pre abstraktné myslenie triviálnost'ou (Heidegger 1991, 20 - 21). Špekulatívna abstrakcia odhliada od aktuálneho jedinca, ktorý je tu a teraz. Jej záber je preto jednostranný: nie je schopná mysliet' všeobecné a jednotlivé spolu. Kierkegaardovo myslenie ponúka syntézu jednotlivého a všeobecného prostredníctvom pojmu existencie.

Pojem existencie je diferencovaný a vzt'ahuje sa na dve podoby existencie: len tak existovat' a opravdivo existovat'. Prvá podoba je základná, takúto existenciu „má“ každý človek a uskutočňuje sa „takmer sama od seba“. Je prejavom toho, že „všetci sme ako ,subjekty“ určení ,subjektivitou“, uvedomeným spôsobom sa vzt'ahujeme $\mathrm{k}$ veciam a sebauvedomeným spôsobom sa vzt’ahujeme k sebe samým. A práve táto subjektivita je ,existenciou“" (Heidegger 1991, 21). Druhá podoba predpokladá zaujatost' existenciou a vzt’ahuje sa len na určitý existenciálny výkon. Podl'a Heideggera takúto existenciu charakterizujú štyri momenty: 1. Jednotlivý človek uvedomeným spôsobom preniká do svojej existencie. Takýto prienik sa vyznačuje premyslenost'ou, svedomitost'ou a zodpovednost'ou. Človek odhal'uje korene svojho sebauvedomenia a spoznáva svoje zakorenenie. 2. Súčast'ou prieniku je prekročenie vlastnej existencie: človek prekračuje časovost' a vniká do večného. Vedome predstupuje pred Boha a stojí pred ním. 3. Takéto prekročenie nie je fantastickým únikom z časovosti a jedinec sa nerozplýva $\mathrm{v}$ absolútne ako $\mathrm{v}$ prípade špekulatívnej abstrakcie. Zostáva prítomný v časovej existencii a udržuje nekonečný rozdiel medzi časom a večnost’ou. 4. Prienik do večnosti a zotrvávanie v časovosti - existencia ako syntéza - sa vyznačuje procesuálnost'ou, stávaním sa. Konanie $\mathrm{v}$ časovosti je priblížením $\mathrm{k}$ večnosti (Heidegger 1991, 23 - 24).

Heidegger zakončuje túto reflexiu kierkegaardovského pojmu existencie tým, že ju vyjadruje v krest’anských existenciálnych pojmoch: syntéza večnosti a časovosti, nekonečnosti a konečnosti je základom autentického bytia-krest’anom: „neustále stávanie-sa-krest'anom; na základe viery v skutočnost' vtelenia Boha v Kristovi rozumiet' sebe samému ako tomu, kto koná pred Bohom - to znamená: ,opravdivo existovat"“" (Heidegger 1991, 24).

Heideggerova bilancia Kierkegaardovho pojmu existencie $\mathrm{v}$ spisoch $\mathrm{z}$ roku 1941 ukazuje, že Heidegger číta Kierkegaarda cez prizmu Anti-Climaca - 
Kierkegaardovho pseudonymu, ktorý reprezentuje autentickú krest’anskú existenciu (Šajda 2017, 627 - 629). Heidegger prezentuje súvislý výklad Anti-Climacovej pozície z diela Choroba na smrt ${ }^{5}$ a interpretuje ju ako Kierkegaardovu vlastnú pozíciu. $\mathrm{Z}$ tejto perspektívy pristupuje $\mathrm{k}$ pozíciám d'alších Kierkegaardových pseudonymov. Heideggerove neskoršie spisy neprinášajú korekciu alebo alternatívu bilancie Kierkegaardovho myslenia v spisoch z roku 1941.

\section{Levinas a Henry: Od subjektivity k etike a spät'}

Emmanuel Levinas patril k prvým filozofom, ktorí Husserlovo a Heideggerovo myslenie predstavili francúzskej verejnosti. Levinas navštevoval Husserlove prednášky vo Freiburgu v rokoch 1928 - 1929, ked' vrcholila kierkegaardovská renesancia. Po návrate do Francúzska bol Levinas v kontakte s viacerými poprednými predstavitel'mi francúzskej kierkegaardovskej renesancie vrátane Jeana Wahla a Leva Šestova. Na Šestovovu knihu Kierkegaard a existenciálna filozofia v roku 1937 Levinas napísal recenziu.

Levinasova recepcia Kierkegaardovho myslenia sa koncentruje $\mathrm{v}$ dvoch dielach: Existencia a etika a A propos „Kierkegaard vivant“. Obe vyšli v šest'desiatych rokoch 20. storočia a Levinas ich neskôr zaradil do zbierky Vlastné mená. Krátke odkazy na Kierkegaarda nájdeme aj v iných spisoch, no sú len variáciami momentov, ktoré Levinas predstavil v týchto dielach (Hanson 2012, 181).

Za klúčové možno označit tri momenty Levinasovej recepcie. Prvým je reflexia Kierkegaardovho protestu proti rozplynutiu subjektivity $\mathrm{v}$ hegelovskom špekulatívnom idealizme. Podl’a Levinasa Kierkegaard prejavil správnu filozofickú intuíciu, ked’ kritizoval idealistický kult univerzálneho rozumu. V univerzalistických štruktúrach ducha sa subjektivita redukuje na „nehmotný bod“ (Levinas 1976a, 77) a stáva sa prchavým momentom celku. Pravdou je celok, nie jedinec, a preto sa všetko osobité a jedinečné marginalizuje v hegemónii spoločného a všeobecného. Človek sa stáva obet'ou vlastného výtvoru: intelektuálne štruktúry ducha, ktoré vytvoril, si ho podrobujú a absorbujú ho. Levinas používa metaforu obrazu, ktorý pohltil svojho tvorcu (Levinas 1976a, 78). Kierkegaardov odpor voči totalite absolutizovaného a systematizovaného rozumu je dôležitý aj z politického hl'adiska, lebo umožňuje kritiku koncepcie „vít'aznej pravdy“, na ktorej stoja totalitné režimy. Hoci Levinas oceňuje Kierkegaardovu snahu o rehabilitáciu subjektivity, upozorňuje, že Kierkegaardova korekcia smeruje k neadekvátnej koncepcii subjektivity. Subjektivita je oddelená od iných, je to „exhibicionistická subjektivita“ bez

\footnotetext{
${ }^{5} \mathrm{~K}$ širšej fenomenologickej interpretácii tohto diela pozri Welz (2013, 442 - 443). Miesto AntiClimaca v Kierkegaardovej tvorbe analyzuje J. Marek (2015).
} 
Druhého (Levinas 1976b, 89). Egoistická a do seba zahl'adená subjektivita nepreberá zodpovednost' a zostáva v línii filozofických koncepcií nadradeného subjektu, ktoré sú rozšírené v modernej západnej filozofii. Levinas vidí v Kierkegaardovom ostrom proteste proti idealizmu, v náuke o oddelenej subjektivite, ako aj v spôsobe ich prezentácie agresivitu, tvrdost’, ba dokonca násilie. Toto násilie ho „šokuje“ a Kierkegaardovo myslenie, ktoré je „permanentným škandálom [a] odporom proti všetkému,“ považuje za filozofovanie kladivom ešte pred Nietzschem (Levinas 1976a, 84; Levinas 1976b, 89). Poukazuje na pokračovanie tohto spôsobu filozofovania až do súčasnosti, pričom ho neváha spojit's národným socializmom. Kierkegaardova intelektuálna nespútanost' je predzvest'ou fatálneho zneužitia jazyka v despotizme 20. storočia (Levinas 1976b, 89). Levinasovým ciel'om je predstavit' alternatívnu koncepciu subjektivity, ktorá na jednej strane vzdoruje totalizujúcim tendenciám špekulatívneho idealizmu a na druhej strane koriguje extrémnost' Kierkegaardovho prístupu.

Druhým momentom je Levinasova kritika Kierkegaardovej teórie existenciálnych štádií, ktorá vychádza z kritiky subjektivity. Podl'a Levinasa Kierkegaard nedokázal adekvátne ukotvit' koncepciu subjektivity aj preto, lebo jeho teória štádií obsahuje neudržatel'nú koncepciu etiky. Idea troch existenciálnych štádií - estetického, etického a náboženského - je síce zmyslupná, no v jej jadre je nepochopenie podstaty etiky. Podozrenie voči všeobecnému anonymnému systému, ktoré charakterizuje Kierkegaardov spor s idealizmom, je prítomné aj v teórii štádií a vedie $\mathrm{k}$ deformovanému pohl'adu na sféru etického. Kierkegaard charakterizuje etické ako všeobecné, ktoré platí vždy a všade, pre všetkých rovnako. Etické štádium preto nemôže byt' konečným ciel'om existenciálneho rozvoja, lebo jedinec by sa v ňom rozplynul pod tlakom všeobecnej normativity. $V$ anonymnom etickom poriadku niet miesta pre jeho osobitost'. Kierkegaard preto motivuje jedinca k „,prekročeniu etiky“ a prechodu do náboženského štádia (Levinas 1976b, 89 - 90). Levinasova kritika sa sústred'uje na tento moment, ktorý interpretuje ako spojenie subjektivity s náboženskost’ou za cenu marginalizácie etiky. Ked' sa vzt’ah jedinca k Bohu oddelí od vzt'ahu k druhému človeku, vzniká priestor pre násilie. Levinas koriguje Kierkegaardovu myšlienkovú líniu vlastnou koncepciou etiky, ktorej základom je náuka o stretnutí s Druhým. Proti radikálnemu egoizmu stavia radikálny altruizmus, ktorý zdôrazňuje zodpovednost' za Druhého: „Ja, ktoré je pred Druhým, je nekonečne zodpovedné“ (Levinas 1976a, 86). Byt' sebou znamená „nemôct' sa vyhnút' tejto zodpovednosti“ (Levinas 1976a, 85), pričom zodpovednost' „zbavuje Ja jeho imperializmu a egoizmu“ (Levinas, 1976a, 86). Etika, ktorá vychádza zo zodpovednosti 
za Druhého, nerozpúšt’a subjektivitu vo všeobecnosti, pretože len „neredukovatel'nác subjektivita môže vedome a samostatne prevziat' zodpovednost' za Druhého (Levinas 1976a, 85).

Tretím momentom je koncepcia trpiacej pravdy, ktorá sa nachádza na pomedzí epistemológie, etiky a filozofie náboženstva. Levinas označuje túto pravdu aj ako prenasledovanú a kladie ju do protikladu k vít'aznej pravde. Kierkegaard sa podl'a neho vymedzuje voči dominantnému názoru, že pravda je tam, kde je vít’azstvo. Kierkegaardovskou alternatívou vít'aznej pravdy je viera, ktorá nie je „nedostatočným poznaním“, ale vzt’ahom k „pravde, ktorá trpí a je prenasledovaná“ (Levinas 1976a, 80 - 81). Táto pravda má u Kierkegaarda krest’anský obsah, vzdoruje asimilácii do totality a nemôže byt’ predmetom vlastníctva. Jej povaha je transcendentná, preto ju nemožno - na rozdiel od priehl'adnej pravdy intelektuálnych systémov - úplne odkryt' a sprístupnit'. Ked’že sa vymyká uchopeniu, spája sa s ňou ustavičná neistota. Táto pravda sa zjavuje v extrémnej pokore a je manifestáciou božského. Aj v tomto bode však Levinas kritizuje Kierkegaarda za absenciu zodpovednosti za Druhého. Hladanie pravdy Kierkegaard chápe ako „vnútornú drámu“ a trpiaca pravda podnecuje jedinca $\mathrm{k}$ budovaniu vzt'ahu $\mathrm{k}$ Bohu v samote, bez zahrnutia druhých (Levinas 1976a, 82). Kierkegaardov inovatívny a škandalózny pojem pravdy je v konečnom dôsledku poznačený rovnakým egoizmom, aký sa prejavil $\mathrm{v}$ jeho filozofii subjektivity. Tento egoizmus je podporený nesprávnou koncepciou etiky, v ktorej Kierkegaard vidí ohrozenie jedincovej samostatnosti.

Hoci Michel Henry vstúpil do diskurzu o Kierkegaardovi až po druhej svetovej vojne, súčast'ou jeho recepcie je aj pokus vyrovnat' sa s autormi kierkegaardovskej renesancie, najmä s Heideggerom a Wahlom. Henry reflektuje Kierkegaardove filozofické pozície vo viacerých dielach, no jeho explicitná recepcia sa na mnohých miestach obmedzuje na krátke odkazy a poznámky. S rozsiahlejšou recepciou sa stretávame v dielach Podstata javenia (1963) a Vtelenie. Filozofia živého tela (2000). Za klúčové pokladáme prvé, pretože v ňom si Henry osvojuje Kierkegaardovu teóriu subjektivity spôsobom, ktorý je smerodajný pre d’alšie diela. V Podstata javenia Henry objasňuje „zmysel bytia ega“ a skúma, čo tým myslíme, ked’ hovoríme Ja v situácii, v ktorej ide o nás samých (Henry 2003, 1). Henry spája túto tému s Kierkegaardom a nadväzuje na jeho teóriu Ja v diele Choroba na smrt'. Henry preberá pojem zúfalstva, ktoré má $\mathrm{v}$ Kierkegaardovom chápaní dialektický charakter: na jednej strane je prejavom narušeného vzt'ahu k sebe samému, na druhej strane človeku pripomína, ako mu je jeho Ja dané. Henryho recepcia Kierkegaardovho pojmu zúfalstva je pozitívna - integruje ho do štruktúr svojho myslenia a rozvíja ho. 
Henryho vyrovnávanie s pojmom zúfalstva sa začína odmietnutím obrazu Kierkegaarda, ktorý predstavil Heidegger. Henry zdôrazňuje, že „musíme kategoricky odmietnut' Heideggerovo tvrdenie, podl'a ktorého Kierkegaard uchopil problém existencie len ako existencielný problém“ (Henry 2003, 851). Tiež musíme odmietnut' tvrdenie, že v oblasti ontológie bol Kierkegaard závislý od Hegela a hegelovského chápania antickej filozofie. Henry poukazuje na Kierkegaardovo rozpracovanie fundamentálnych afektívnych tonalít existencie - najmä utrpenia -, ktoré ukazuje, že skúmanie existencie neobmedzoval na existencielnú perspektívu a jeho koncepcia ontológie sa radikálne líšila od hegelovskej, „gréckej“ či heideggerovskej (Henry 2003, 851). Kierkegaard situuje fundamentálne afektívne tonality existencie do „štruktúry samého bytia, do vnútornej štruktúry imanencie“, preto aj zúfalstvo, ktoré je najintenzívnejšou podobou utrpenia, nemožno pochopit' inak ako vo vzt'ahu $\mathrm{k} J \mathrm{a}$ (Henry 2003, 850 - 851). Kierkegaard upozornil na to, že hoci sa často zdá, že zúfalstvo prichádza zvonku, jeho podstata vždy tkvie vo vzt’ahu k sebe samému. Henry preberá dve základné formy zúfalstva - nechciet' byt' sám sebou a chciet' byt' sám sebou -, ktoré opisuje pomocou vlastnej terminológie. Prvá forma sa vyznačuje tým, že Ja sa usiluje „,pretrhnút’ puto, ktoré ho spája so sebou samým“ (Henry 2003, 852), pokúša sa rozbit' svoju vlastnú štruktúru a popriet' to, ako bolo dané sebe samému. Henry súhlasí s Kierkegaardom, že Ja je vzt'ah k sebe samému, ktorý „ustanovilo niečo iné“ (Henry 2003, 852), teda Ja neustanovilo samo seba a nedalo samo seba sebe samému. Je dané niečím iným a je dané spôsobom, ktorý nie je jeho vlastným výtvorom. Práve proti tejto skutočnosti sa Ja vzpiera, ked' sa chce zbavit' seba samého - ked' nechce byt' sebou samým. Opät' v súlade s Kierkegaardom Henry poznamenáva, že Ja sa nedokáže zbavit' seba samého a nedokáže pretrhnút' puto, ktoré ho viaže $\mathrm{k}$ sebe v jeho danosti (Henry 2003, 853). Opakovaná snaha oddelit' sa od seba samého, ktorá je odsúdená na neúspech, predstavuje „monštruózne protirečenie“, ktoré charakterizuje l'udskú existenciu (Henry 2003, 853). Ja sa pokúša zničit” „to, čo ho konštituuje, to, čo v ňom konštituuje život“ (Henry 2003, $854)$, chce zomriet', no nemôže. Preto je zúfalstvo „len“ chorobou na smrt', ${ }^{6}$ nie smrt’ou ako takou. Je večným zomieraním, ktoré nie je ukončené smrtou. V tomto momente Henry prechádza $\mathrm{k}$ téme života, ktorá nie je prítomná v Kierkegaardových úvahách, no zohráva klúčovú úlohu v jeho vlastnej filozofii. Henry vysvetl'uje, že ,zúfalstvo nesie v sebe život... jeho vôl'a zomriet' nie je smrt'ou, ale spôsobom života“ (Henry 2003, 854). Hoci je zúfalstvo sebapopretím, nie je v jeho moci zničit’ to, čo život dáva: ,nerozlučnú jednotu toho, že Ja je dané sebe ako spôsob večného a absolútneho života“ (Henry 2003, 855). Zúfalstvo ako

\footnotetext{
${ }^{6}$ Henry v nadväznosti na Kierkegaarda rozvíja vlastnú filozofiu patológie, ktorá v 19. a 20. storočí predstavovala zvláštny filozofický žáner. Viac k tejto téme uvádza A. Vydra (2015).
} 
sebaodmietnutie je prítomné v každej forme života a jeho snaha oddelit' Ja od seba samého je vždy len novým spôsobom života.

Henry poukazuje aj na druhú podobu zúfalstva - chciet' byt' sám sebou -, ktorá je dialektickým protipólom prvej podoby. $\mathrm{V}$ tomto type zúfalstva chce Ja byt' samo sebou iným spôsobom, než ako je samo sebe dané. Chce byt' takým Ja, akým nie je - chce od základu vytvorit' samo seba. Takéto zúfalstvo zahŕňa „všetky predstavitel'né spôsoby života, v ktorých Ja nahrádza seba iným Ja, s ktorým sa stotožňuje“ (Henry 2003, 856). Podobne ako pri prvej podobe zúfalstva aj tu Ja naráža na hranice svojich možností. Nie je schopné vytvorit' radikálne nové Ja, život ho vrhá spät' $\mathrm{k}$ tomu Ja, ktoré mu je dané. Ked' sa zmieta v zúfalstve a zažíva jeho rôzne podoby, rastie $\mathrm{v}$ ňom napätie a zintenzívňuje sa vnútorné protirečenie. Tento proces je však podl’a Henryho i Kierkegaarda plodný, lebo núti Ja konfrontovat' sa so sebou samým. Zážitok nemožnosti zbavit' sa seba samého a vytvorit' alternatívne Ja je zároveň zážitkom toho, že Ja je nútené byt' sebou - je to „zážitok toho, že je dané sebe samému, je to zážitok podstaty života v sebe“ (Henry 2003, 857). V tonalite zúfalstva sa tak odkrýva možnost' byt' sám sebou a zjavuje sa moc, ktorá ustanovila Ja a ku ktorej sa Ja chtiac-nechtiac vzt'ahuje. Henry takto produktívne využíva Kierkegaardovu teóriu Ja pri rozvoji svojej filozofie života. V neskoršom diele Vtelenie. Filozofia živého tela ju prepojí s filozofiou telesnosti a náukou o živom tele (Henry 2000, 270 - 284; Stan 2011, 138 - 143).

\section{Prieniky, napätia, protirečenia a d'alší smer výskumu}

V centre záujmu všetkých troch fenomenologických myslitel'ov je Kierkegaardovo chápanie existencie a subjektivity a jeho eticko-náboženský rozmer. Všetci traja predstavujú Kierkegaarda ako významného a novátorského myslitel’a, ktorého myšlienkový projekt inšpiroval ich vlastnú tvorbu. Preberajú jeho tematické dôrazy a rozvíjajú ich originálnym spôsobom $\mathrm{v}$ intenciách svojho myslenia. Kierkegaardove podnety integrujú do nových kontextov. U Heideggera a Levinasa vidíme súhru potvrdenia kierkegaardovských tém s odmietnutím kierkegaardovského spôsobu ich spracovania. Obidvaja žiadajú nový prístup k otázke existencie a subjektivity, svoje vlastné pozície budujú v kontraste ku Kierkegaardovým pozíciám. Henryho recepcia neobsahuje výrazný kritický moment, naopak, usiluje sa „rehabilitovat" Kierkegaardov pohl'ad na otázku existencie a subjektivity. Popri prienikoch existujú medzi fenomenologickými interpretáciami aj závažné rozdiely, v niektorých ohl’adoch si odporujú a napätia nájdeme aj v rámci jednotlivých interpretácií.

Najvýraznejším vnútorným napätím je rozdiel medzi Heideggerovou interpretáciou Kierkegaardovho pojmu existencie v druhom cykle prednášok o Schellingovi 
a v d’alších dvoch skúmaných spisoch. V prednáškach o Schellingovi Heidegger identifikuje u Kierkegaarda dve súčasti pojmu existencie: existenciu $v$ širšom zmysle (,len tak existovat"“) a existenciu v užšom zmysle (,opravdivo existovat"“). V prvom prípade hovorí o subjektivite - o elementárnom sebauvedomenom vzt'ahu $\mathrm{k}$ sebe samému a uvedomenom vzt'ahu $\mathrm{k}$ inému. $\mathrm{V}$ druhom prípade hovorí o podobe existencie, ktorá je ciel'om a dosahuje sa určitým eticko-náboženským konaním. Toto rozlíšenie - hoci nie je vyjadrené Kierkegaardovými vlastnými pojmami zodpovedá Kierkegaardovej teórii Ja v diele Choroba na smrt'. Problém tkvie v tom, že vo zvyšných dvoch spisoch Heidegger berie do úvahy len existenciu v užšom zmysle slova. Podrobuje ju kritike a Kierkegaardovi vyčíta radikálne zúženie pojmu existencie. Tvrdí, že Kierkegaard podmienil existenciu eticko-náboženským výkonom a stotožnil ju so stávaním sa krest’anom. Táto kritika však neplatí, ak vezmeme do úvahy obe súčasti pojmu existencie. Heidegger teda kritizuje jednu súčast’ pojmu existencie akoby to bol celý pojem. Kritiku Kierkegaardovho „zúženého“ a „existencielného“" pojmu existencie potom využíva ako východisko pre svoje širšie „existenciálne" uchopenie otázky existencie.

Proti Heideggerovej téze, že eticko-náboženský moment limituje Kierkegaardov pojem existencie, stavia Levinas tézu, že tento moment nie je u Kierkegaarda dostatočne rozvinutý. Levinas ho považuje za nevyhnutný pre komplexné rozpracovanie teórie subjektivity a Kierkegaardovi vyčíta, že náboženský pól oddel'uje od etického pólu. Táto skutočnost' diskvalifikuje Kierkegaardovu teóriu existenciálnych štádií, ked’že stavia do opozície etické a náboženské štádium. To, čo je etické, má byt' prekonané, a preto sa mu nevenuje adekvátna pozornost'. Levinas koriguje Kierkegaardovu „egoistickú“ subjektivitu vlastnou koncepciou etiky, ktorá zdôrazňuje jedincovu zodpovednost' za Druhého. Levinas však oceňuje Kierkegaardov zámer vybudovat' teóriu subjektivity na novom základe, v priamej opozícii voči špekulatívnemu idealizmu. V tomto bode sa zhoduje s Heideggerom, ktorý však vidí u Kierkegaarda väčšiu závislost' od hegelovských koncepcií.

Východiskom Henryho reflexie Kierkegaardovej teórie Ja je odmietnutie Heideggerovej tézy o Kierkegaardovej ontologickej závislosti od Hegela ako aj tézy o Kierkegaardovom „zúženom“ pojme existencie. Henry predstavuje Kierkegaardovu teóriu subjektivity v pozitívnom svetle a považuje jeho odklon od špekulatívneho idealizmu za vydarený. Na rozdiel od Heideggera neobmedzuje Kierkegaardov pojem existencie na jeho formačný aspekt, ale akceptuje ho v celej šírke. Eticko-náboženskú dimenziu tohto pojmu nepovažuje za prít'až, lebo vidí jej zmysel v kontexte existenciálnej výzvy prekonania zúfalstva. Rovnako ako Heidegger, Henry pracuje najmä s motívmi prevzatými z Kierkegaardovho diela Choroba na $s m r t$, ktoré však interpretuje výrazne odlišným spôsobom. 
V predkladanej analýze sme nastolili tému fenomenologickej recepcie Kierkegaardovho myslenia a určili jej základné súradnice. Náš záber sa obmedzil na troch hlavných predstavitel'ov fenomenologického hnutia, ktorí najvýraznejšie recipovali Kierkegaardove idey, pričom sme skúmali ich explicitnú recepciu. Načrtnutú trajektóriu výskumu možno rozvinút' d’alšími smermi. Predmetom záujmu môžu byt' recepcia u ostatných predstavitel'ov fenomenologického hnutia, implicitné podoby recepcie, tematické línie i porovnanie charakteru recepcie počas kierkegaardovskej renesancie a po nej. Nové výskumné výsledky by obohatili diskusiu o vzt'ahu fenomenológie a filozofie existencie, ktorá sa postupne rozvíja $\mathrm{v}$ našom priestore.

\section{Literatúra}

ELERT, W.: Der Kampf um das Christentum. Geschichte der Beziehungen zwischen dem evangelischen Christentum in Deutschland und dem allgemeinen Denken seit Schleiermacher und Hegel. München: Beck 1921.

HANSON, J. (2012): Emmanuel Levinas: An Ambivalent but Decisive Reception. In: Stewart, J. (ed.): Kierkegaard's Influence on Philosophy, Tome III: Francophone Philosophy (Kierkegaard Research: Sources, Reception and Resources, vol. 11). Farnham: Ashgate, 173 - 205.

HEIDEGGER, M. (1961): Entwürfe zur Geschichte des Seins als Metaphysik. In: Nietzsche, Bd. 1. Pfullingen: Neske.

HEIDEGGER, M. (1991): Die Metaphysik des deutschen Idealismus. In: Gesamtausgabe. Frankfurt am Main: Vittorio Klostermann, Bd. 49.

HEIDEGGER, M. (1992): Die Grundbegriffe der Metaphysik. In: Gesamtausgabe. Frankfurt am Main: Vittorio Klostermann, Bd. 29/30.

HEIDEGGER, M. (2014): Überlegungen XII - XV. In: Gesamtausgabe. Frankfurt am Main: Vittorio Klostermann, Bd. 96.

HENRY, M. (2000): Incarnation. Une philosophie de la chair. Paris: Seuil.

HENRY, M. (2003): L'Essence de la manifestation. Paris: Presses universitaires de France.

LEVINAS, E. (1976a): Kierkegaard/Existence et éthique. In: Noms propres. Montpellier: Fata Morgana, $77-87$.

LEVINAS, E. (1976b): A propos de „Kierkegaard vivant“. In: Noms propres. Montpellier: Fata Morgana, 88 - 92.

MAREK, J.: Anti-Climacus: Kierkegaard's „Servant of the Word“. In: Nun, K. a Stewart, J. (eds.): Kierkegaard's Pseudonyms (Kierkegaard Research: Sources, Reception and Resources, vol. 17). Aldershot: Ashgate, 39 - 50.

OLŠOVSKÝ, J. (2013): Heidegger a Kierkegaard. Na cestě k myšlení. Praha: Akropolis.

STAN, L. (2011): Michel Henry: The Goodness of Living Affectivity. In: Stewart, J. (ed.): Kierkegaard and Existentialism (Kierkegaard Research: Sources, Reception and Resources, vol. 9). Farnham: Ashgate, $127-154$.

ŠAJDA, P. (2016): Kierkegaardovská renesancia. Filozofia, náboženstvo, politika. Bratislava: Premedia.

ŠAJDA, P. (2017): Kierkegaard - existencia, bytie sebou, stávanie sa krest’anom. In: Leško, V., Sobotka, M. a kol.: Heidegger a novoveká metafyzika. Košice: FF UPJŠ, 611 - 630 .

THONHAUSER, G. (2016a): Ein rätselhaftes Zeichen. Zum Verhältnis von Martin Heidegger und Søren Kierkegaard. Berlin - Boston: De Gruyter.

THONHAUSER, G. (2016b): Sociálna filozofia v diele Bytie a čas so zvláštnym zretel’om na Kierkegaardovu rolu. Preložila L. Hábová. Filozofia, 71 (4), 292 - 303. 
TURNBULL, J. (2012): Edmund Husserl: Naturalism, Subjectivity, Eternity. In: Stewart, J. (ed.): Kierkegaard's Influence on Philosophy, Tome I: German and Scandinavian Philosophy (Kierkegaard Research: Sources, Reception and Resources, vol. 11). Farnham: Ashgate, $147-162$.

VYDRA, A. (2015): Sociálna patológia - filozofický pojem, alebo zle zvolená metafora? Filozofia $70(9), 693-702$.

VYDROVÁ, J. (2013): Ja a Ne-Ja: Archeologický prístup k štruktúre jadra v Husserlových textoch o časovej konštitúcii. Filozofia, 68 (1), mimoriadne číslo: Interiorita, exteriorita, responzivita, $36-44$.

WELZ, C. (2013): Kierkegaard and Phenomenology. In: Lippitt, J. a Pattison, G. (eds.): The Oxford Handbook of Kierkegaard. Oxford: OUP.

Tento text vznikol na Filozofickom ústave SAV v Bratislave ako súčast' riešenia grantovej úlohy VEGA č. 2/0110/18.

Peter Šajda

Filozofický ústav SAV

Klemensova 19

81364 Bratislava 1

Slovenská republika

e-mail: filosajd@savba.sk

ORCID ID: https://orcid.org/0000-0003-1567-0704 